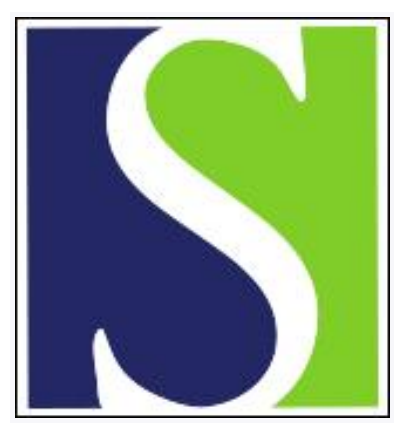

Scand J Work Environ Health 1983;9(5):419-430

https://doi.org/10.5271/sjweh.2392

Issue date: Oct 1983

Tissue distribution of styrene, styrene glycol and more polar styrene metabolites in the mouse.

by Lof A, Gullstrand E, Byfalt Nordqvist M

This article in PubMed: www.ncbi.nlm.nih.gov/pubmed/6673100






\title{
Tissue distribution of styrene, styrene glycol and more polar styrene metabolites in the mouse
}

\author{
by Agneta Löf, MSc, Elisabeth Gullstrand, Marianne Byfält Nordqvist, PhD1
}

\begin{abstract}
LÖF A, GULLSTRAND E, BYFÄLT NORDQVIST M. Tissue distribution of styrene, styrene glycol and more polar styrene metabolites in the mouse. Scand $j$ work environ health 9 (1983) 419-430. A primary objective of the present investigation was to determine the tissue distribution of styrene, styrene glycol, and more polar metabolites in mice at different times $(0.5-5 \mathrm{~h})$ after the in traperitoneal administration of styrene $(3.3 \mathrm{mmol} /$ $\mathrm{kg}$ ). Another aim was to determine the dose dependence of the metabolite pattern of styrene in the different tissues. The dose range chosen was $1.1-4.9 \mathrm{mmol}$ of styrene/kg administered intraperitoneally, and the time delay $2 \mathrm{~h}$ after dosing. The highest initial concentrations of unchanged styrene were found in adipose tissue, pancreas, liver, and brain. Styrene glycol reached its maximum concentration within $1 \mathrm{~h}$ in most tissues. The levels in the kidneys, lungs, pancreas, and liver far exceeded those in subcutaneous adipose tissue. Only in the liver and kidneys was a notable amount of styrene glycol conjugated. Polar metabolites occurred to a considerable extent in the liver, kidneys, lungs, and plasma. The concentration of unmetabolized styrene seemed to increase exponentially with the dose in subcutaneous adipose tissue, liver, kidneys, lungs, and brain. No tendency towards a decreased relative occurrence of styrene glycol was observed at higher doses. However, when the dose was increased, the more polar metabolites occurred at relatively lower levels in all tissues except brain.
\end{abstract}

Key terms: dose dependence, electron capture detector, gas chromatography, highperformance liquid chromatography, metabolism, radiolabeled chemical.

Styrene (vinylbenzene, phenylethylene) is one of the most important monomers used in the plastics and synthetic rubber industry. The most extensive exposure occurs in the production of glass reinforced plastics (38). Styrene enters the organism mainly through the lungs, and absorbed styrene is, according to animal studies, rapidly distributed in the major organ systems $(5,46)$.

The metabolism of styrene can be considered to take place principally in the liver, but extrahepatic tissues may contribute $(7,27,32,40,44)$. The biotransformation is stimulated by styrene itself $(28,33)$. The first step in the major meta-

1 Research Department, National Board of Occupational Safety and Health, S-17184 Solna, Sweden.

Reprint requests to: Ms A Löf, Research Department, National Board of Occupational Safety and Health, S-171 84 Solna, Sweden. bolic pathway is supposedly the formation of styrene-7,8-oxide (phenyloxirane) $(21,22,24,27,43,44)$, a reaction preferentially catalyzed by microsomal cytochrome P-450 (21, 40). Ring hydroxylation of styrene occurs to a smaller extent, as does the formation of phenyl ethanols $(1,26$, $27,40,42$ ). Styrene-7,8-oxide is hydrated to styrene glycol (1-phenyl-1,2-ethanediol) by microsomal epoxide hydratase (23, 43). Furthermore a group of soluble enzymes, glutathione S-transferases, convert the epoxide to glutathione conjugates $(6,31,32)$, which are degraded to mercapturic acids before excretion $(19,35$, 36). Epoxide hydratase and glutathione S-transferase may play protective roles with regard to the toxic effects of styrene7,8 -oxide $(27,40)$.

Styrene glycol can be conjugated with $\beta$-glucuronic acid $(14,26)$ or oxidized to mandelic acid and further to phenylglyoxylic acid, the two main urinary 
metabolites of styrene in man $(2,20)$. In mice mandelic acid is also oxidized to benzoic acid, which, after glycine conjugation, is excreted in the urine as hippuric acid (27).

Styrene glycol has hitherto not been detected in the tissues of mice. Recently it was determined in blood from experimentally exposed volunteers and from occupationally exposed workers $(44,45)$. It had earlier only been found after cleavage with $\beta$-glucuronidase in urine from animals treated with styrene $(14,26)$. The main purpose of this study on mice was, first, to obtain information on the tissue distribution of the styrene monomer and its metabolites and, second, to determine the dose dependence of the conversion of styrene to styrene glycol and to more polar metabolites. Mice were chosen as they are considered one of the species most vulnerable to the toxic effects of styrene on the basis of their enzyme activities in different tissues in vitro and their easily affected levels of reduced glutathione $(7,39)$.

\section{Material and methods}

Radioactively labeled $7-\left[{ }^{14} \mathrm{C}\right]$-styrene (The Radiochemical Centre, Amersham, England; radiochemical purity $98 \%$ and chemical purity $99 \%$ ) with a specific activity of $3.95 \mathrm{MBq} / \mathrm{mmol}$ was mixed with dimethylsulfoxide (Merck, analytical grade) and corn oil (1:1:18) and used as the dosing solution.

For the determination of the distribution of styrene and its metabolites in different tissues, four groups of five male Naval Medical Research Institute mice (25-
$30 \mathrm{~g})$ were injected intraperitoneally with a $3.3-\mathrm{mmol} / \mathrm{kg}$ dose of styrene. The groups were killed after $0.5,1,2$, and $5 \mathrm{~h}$. In a following experiment, three groups of five mice were killed $2 \mathrm{~h}$ after an intraperitoneal injection of styrene at $1.1,2.3$, and $4.9 \mathrm{mmol} / \mathrm{kg}$, respectively. Blood was drawn from the orbital sinus of the eye, and hemoglobin was isolated for the determination of the extent of the alkylation of hemoglobin (to be published). The plasma was kept frozen at $-70^{\circ} \mathrm{C}$ in sealed glass vials until the analysis. Other tissues and organs (liver, kidney, lung, pancreas, spleen, testis, brain, thymus, muscle, subcutaneous adipose tissue, brown adipose tissue) were excised and stored in the same way. Samples from the same kind of tissues from each exposure group were pooled, weighed, and homogenized in $1 \mathrm{M}$ sodium chloride. An aliquot of each homogenate or pooled plasma was solubilized in Soluene $350^{\circledR}$, decolored with hydrogen peroxide when necessary, and mixed with scintillation liquids (8). The radioactivity was assayed in a Packard TriCarb model 3375 spectrometer with external standardization.

Pooled, homogenized tissues were extracted four times at $\mathrm{pH} 6$ with equal volumes of ethyl acetate (Merck, analytical grade) (fig 1, step 1). Conjugated metabolites were cleaved with $\beta$-glucuronidase type $\mathrm{H}-1$ (Sigma) in $0.2 \mathrm{M}$ acetate buffer, $\mathrm{pH} 5.0$, at $37^{\circ} \mathrm{C}$ overnight and extracted three times with ethyl acetate (step 2). An aliquot of each extract and of the remaining aqueous phase was mixed with scintillation fluid (Permablend III $^{\circledR}$ with $20 \%$ ethanol on toluene and Insta-Gel ${ }^{\circledast}$, respectively) and assayed by liquid scintillation counting.

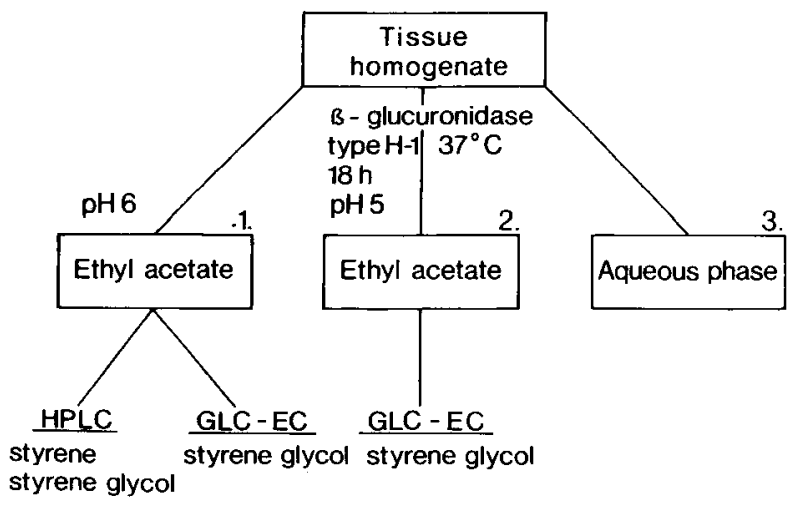

Fig 1. A scheme for the extraction of styrene and styrene glycol (step 1) and conjugated metabolites after cleavage with $\beta$-glucuronidase type $\mathrm{H}-1$ (step 2). The polar metabolites (acids and glutathione conjugates) remain in the aqueous phase after the extractions with ethyl acetate. Extracted styrene and styrene glycol are analyzed by highperformance liquid chromatography (HPLC) and gas chromatography with an electron capture detector (GLCEC) according to the scheme. 
The concentration ratio between styrene and styrene glycol was determined from the ethyl acetate ( $\mathrm{pH} \mathrm{6)}$ extracts by high-performance liquid chromatography on a Micro Pak MCH-10 column $(4 \mathrm{~mm} \times 30 \mathrm{~cm})$. A linear gradient (flow $1.0 \mathrm{ml} / \mathrm{min}$ ) from $30 \%$ methanol in water to $100 \%$ methanol in $11 \mathrm{~min}$ after an initial delay of $4 \mathrm{~min}$ (Varian 5000 liquid chromatograph, Vista 401 chromatography data system) was used. The effluent was monitored at $254 \mathrm{~nm}$. Fractions were collected every $0.5 \mathrm{~min}$ and analyzed by liquid scintillation counting after mixing with Insta-Gel ${ }^{\circledR}$.

The styrene glycol content was specifically determined by gas chromatography with an electron capture detector (3\% SE-30 on Chromosorb GAW-DMCS, $2.0 \mathrm{~m}$, $240^{\circ} \mathrm{C}$, nitrogen flow $40 \mathrm{ml} / \mathrm{min}$, Carlo Erba FTV 2350) after derivatization with pentafluorobenzoyl chloride (Aldrich $98 \%$ ). Allylbenzene glycol was added as the internal standard before and after the cleavage of conjugates by $\beta$-glucuronidase (13).

The peak areas of derivatized styrene glycol and allylbenzene glycol were integrated (Varian Vista 401 chromatography data system). The calibration curves were obtained after the addition of $10 \mu \mathrm{l}$ of toluene solutions of styrene glycol (Aldrich $97 \%$ ) to plasma and tissues after homogenization. The concentration range was $0-100 \mu \mathrm{mol} / \mathrm{l}$ for the styrene glycol. The calibration curves for all tissues except subcutaneous adipose tissue were considered equivalent. The calibration curves were linear for the concentration range in question and could be applied down to a concentration of approximately $1 \mu \mathrm{mol} / \mathrm{l}$. The standard error of the method, as determined on liver samples, was $10 \%$ according to

$$
\mathrm{SE}=\left\{\left[\Sigma d^{2}-(\Sigma d)^{2} / n\right] / 2(n-1)\right\}^{1 / 2},
$$

where $d$ is the difference in concentration between duplicate samples.

\section{Results}

The accumulation of radioactivity in different tissues up to $5 \mathrm{~h}$ after the intraperitoneal administration of styrene- ${ }^{14} \mathrm{C}$ is given in fig 2 . The tissues can be divided into three groups. Subcutaneous adipose tissue had the highest concentration of radioactivity followed by the wellperfused kidneys, liver, and pancreas.

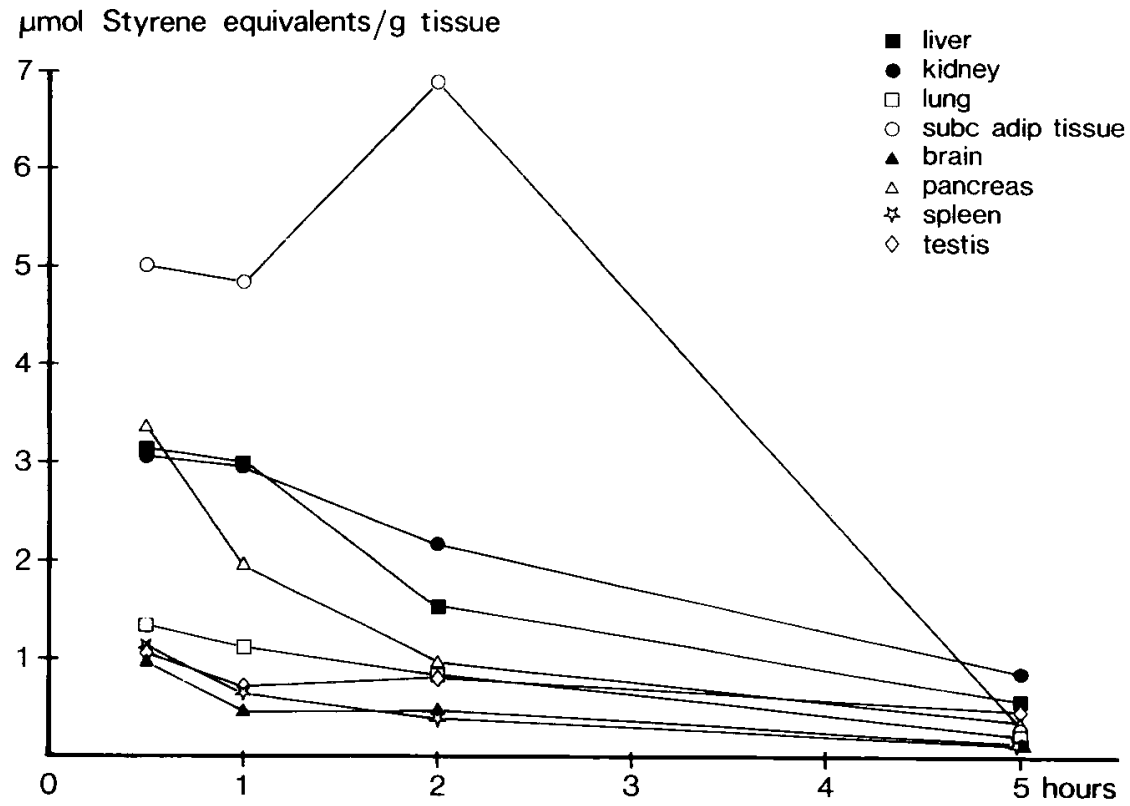

Fig 2. Tissue concentrations of styrene and its metabolites as a function of time after the intraperitoneal administration of $7-\left[{ }^{14} \mathrm{C}\right]$-styrene in a concentration of $3.3 \mathrm{mmol} / \mathrm{kg}$. The concentration of radioactivity is expressed as micromoles of styrene equivalents per gram of wet tissue based on the specific activity of the ${ }^{14} \mathrm{C}$-labeled styrene used. (subc adip = subcutaneous adipose) 

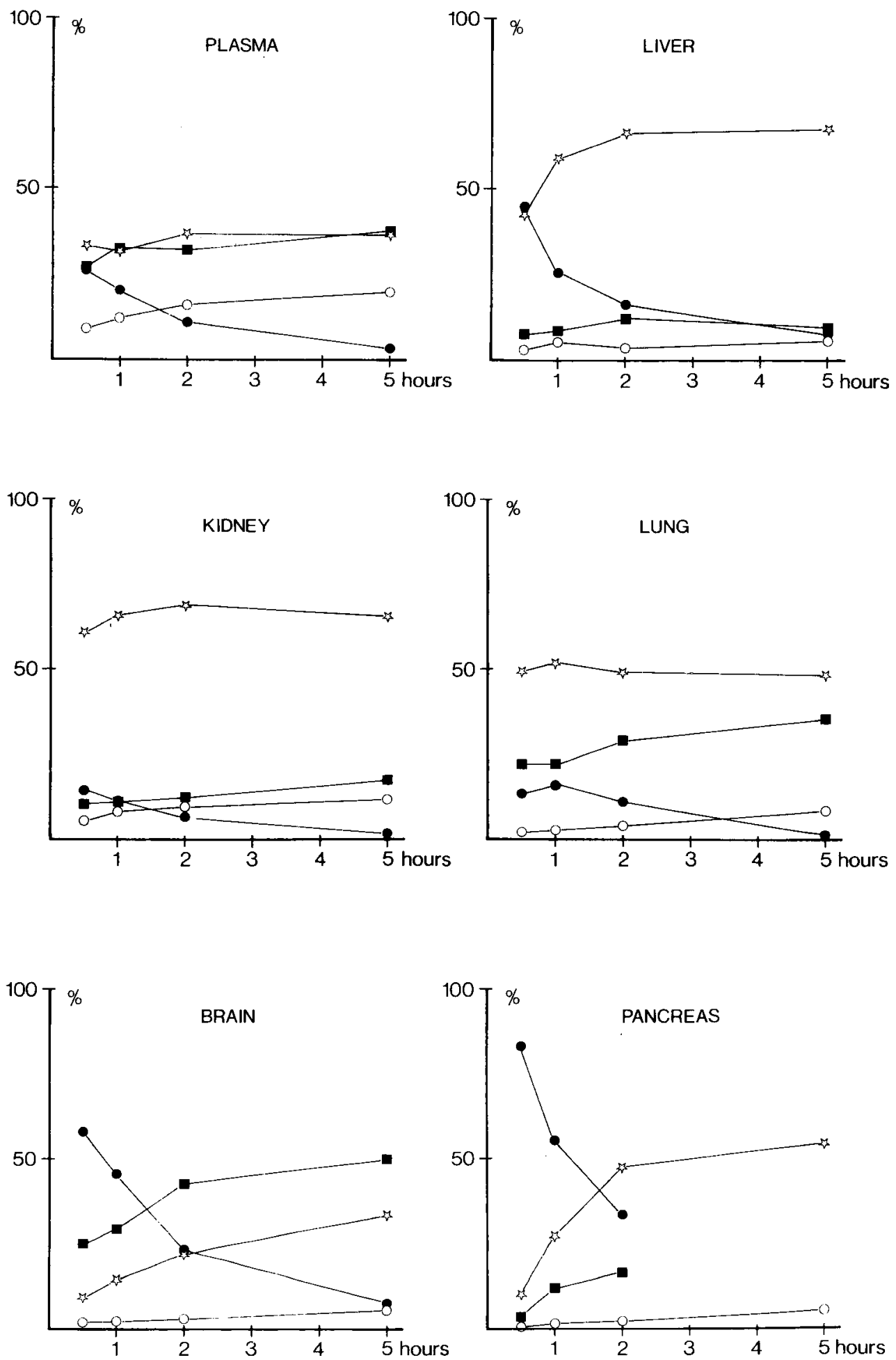

Fig 3. Tissue distribution of styrene (๑), styrene glycol $(\square)$, metabolites hydrolyzed with $\beta$-glucuronidase type $\mathrm{H}-1(0)$, and polar metabolites $(\hbar)$ as a function of time after the intraperitoneal administration of $7-\left[{ }^{14} \mathrm{C}\right]$-styrene in a concentration of $3.3 \mathrm{mmol} / \mathrm{kg}$. The occurrence is expressed as the percentage of total radioactivity in the tissue. The styrene glycol was analyzed by high-performance liquid chromatography. 
The third group consisted of lungs, brain, spleen, and testes. Brown adipose tissue also showed high concentrations of radioactivity, whereas thymus showed intermediate and muscles low levels.

The radioactivity determinations of the different extracts and the analysis by high-performance liquid chromatography made it possible to characterize the radioactivity as the percentage of styrene, styrene glycol, metabolites hydrolyzed with $\beta$-glucuronidase, and polar metabolites. A predominant portion of the radioactivity in the subcutaneous adipose tissue could be considered to be unmetabolized styrene, 90-95\% during the first $5 \mathrm{~h}$. In tissue from the pancreas the level of styrene was very high after $30 \mathrm{~min}$ (about $85 \%$ ) (fig 3 ). Liver, on the other hand, contained a significant portion of polar metabolites. Already after $30 \mathrm{~min}$ the polar metabolites were present in equal amounts as the unmetabolized styrene, a phenomenon supporting a hypothesis of rapid metabolism of styrene in the liver. In plasma the styrene fraction diminished from 25 to $5 \%$ during the first $5 \mathrm{~h}$ after administration, an occurrence reflecting the progress of systemic elimination. Nonconjugated styrene glycol and the more polar metabolites remained relatively constant, about $30-35 \%$. A significant part of the radioactivity in the kidney, about $65 \%$, appeared to represent polar metabolites. Styrene and styrene glycol were present at relatively low levels. In the lungs a considerable fraction of the radioactivity consisted of styrene glycol $(20-35 \%)$ in addition to polar metabolites $(50 \%)$. A high proportion of styrene glycol (25-50\%) was also found in brain tissue. The decline of styrene was very fast in the brain, as well as in the liver and pancreas (fig $3 \& 4$ ).

The concentrations of styrene glycol, both free and conjugated with $\beta$-glucuronic acid or sulfate, as determined by

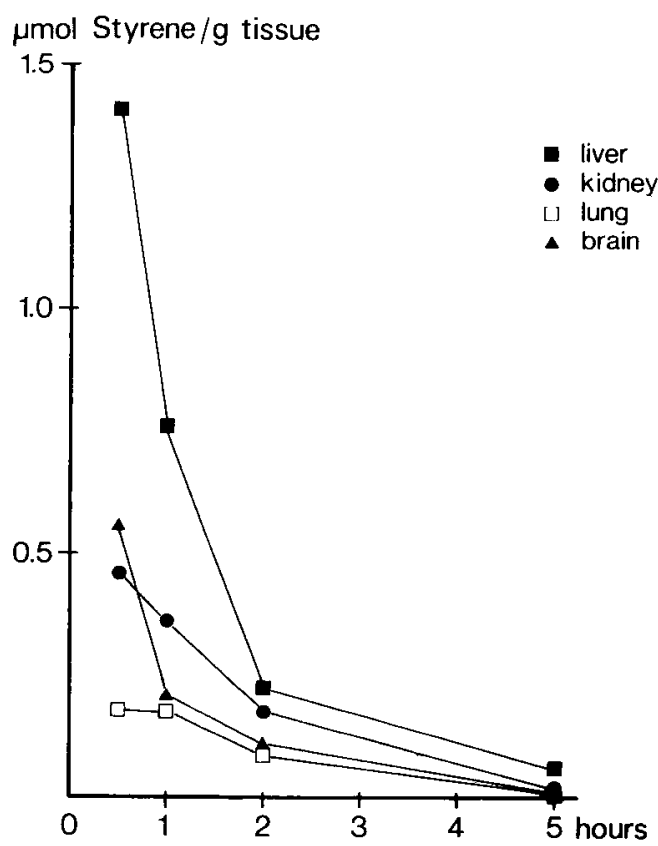

Fig 4. Tissue concentrations of unmetabolized styrene as a function of time after the intraperitoneal administration of $7-\left[{ }^{14} \mathrm{C}\right]$-styrene in a concentration of $3.3 \mathrm{mmol} / \mathrm{kg}$. The concentration of styrene is expressed as micromoles of styrene per gram of wet tissue.

Table 1. Tissue concentrations of styrene glycol, both free and conjugated with $\beta$-glucuronic acid or sulfate, at different times after the intraperitoneal administration of $7-\left[{ }^{14} \mathrm{C}\right]$-styrene in a concentration of $3.3 \mathrm{mmol} / \mathrm{kg}$. The concentration of styrene glycol was determined by gas chromatography.

\begin{tabular}{|c|c|c|c|c|c|c|c|c|}
\hline \multirow{3}{*}{ Tissue } & \multicolumn{8}{|c|}{ Time of administration } \\
\hline & \multicolumn{2}{|c|}{$0.5 \mathrm{~h}$} & \multicolumn{2}{|c|}{$1 \mathrm{~h}$} & \multicolumn{2}{|c|}{$2 \mathrm{~h}$} & \multicolumn{2}{|c|}{$5 \mathrm{~h}$} \\
\hline & Free $^{a}$ & $\begin{array}{l}\text { Conju- } \\
\text { gated }\end{array}$ & Free $^{a}$ & $\begin{array}{l}\text { Conju- } \\
\text { gated }^{a}\end{array}$ & Free $^{a}$ & $\begin{array}{l}\text { Conju- } \\
\text { gated }^{a}\end{array}$ & Freea & $\begin{array}{l}\text { Conju- } \\
\text { gateda }^{2}\end{array}$ \\
\hline $\begin{array}{l}\text { Liver } \\
\text { Kidney } \\
\text { Lung } \\
\text { Brain } \\
\text { Pancreas } \\
\text { Subcutaneous }\end{array}$ & $\begin{array}{r}101.0 \\
193.6 \\
215.8 \\
69.5 \\
129.2\end{array}$ & $\begin{array}{r}35.3 \\
32.8 \\
5.3 \\
1.6 \\
4.6\end{array}$ & $\begin{array}{l}130.6 \\
179.0 \\
198.1 \\
107.2 \\
178.5\end{array}$ & $\begin{array}{r}49.4 \\
69.5 \\
9.3 \\
6.7 \\
6.9\end{array}$ & $\begin{array}{l}134.1 \\
160.0 \\
152.9 \\
100.2 \\
167.1\end{array}$ & $\begin{array}{r}12.2 \\
29.8 \\
11.2 \\
1.9 \\
7.1\end{array}$ & $\begin{array}{l}38.7 \\
66.2 \\
42.3 \\
36.0 \\
51.4\end{array}$ & $\begin{array}{r}4.3 \\
41.3 \\
3.0 \\
0.6 \\
2.5\end{array}$ \\
\hline $\begin{array}{l}\text { adipose tissue } \\
\text { Spleen } \\
\text { Testis }\end{array}$ & $\begin{array}{r}37.8 \\
79.3 \\
118.6\end{array}$ & $\begin{array}{l}- \\
- \\
-\end{array}$ & $\begin{array}{r}40.0 \\
101.1 \\
131.7\end{array}$ & $\begin{array}{l}- \\
\overline{3.0}\end{array}$ & $\begin{array}{r}50.5 \\
98.4 \\
134.0\end{array}$ & $\begin{array}{l}- \\
- \\
4.5\end{array}$ & $\begin{array}{l}16.4 \\
15.2 \\
37.4\end{array}$ & $\begin{array}{l}- \\
- \\
1.4\end{array}$ \\
\hline
\end{tabular}

a Styrene glycol (nmol/g wet tissue). 
gas chromatography with an electron capture detector, are given in table 1 . Only in the liver and kidneys did a notable amount of styrene glycol occur bound to $\beta$-glucuronic acid or sulfate. After $30 \mathrm{~min}$ the kidneys and lungs had the highest total concentrations of styrene glycol (fig 5). A maximum appeared in most tissues within $1 \mathrm{~h}$, the kidneys, lungs, pancreas, and liver showing the highest values and subcutaneous adipose tissue having the lowest.

In all tissues styrene glycol reached its maximum concentration within $2 \mathrm{~h}$. Thus, for the evaluation of the effect of dose, mice were killed $2 \mathrm{~h}$ after the intraperitoneal administration of styrene. The radioactivity in all tissues increased linearly with the dose (fig 6), with a possible exception of that in subcutaneous and brown adipose tissue, a finding reflecting the exponential rise of styrene in these tissues. Similarly the concentration of unmetabolized styrene seemed to increase exponentially with the dose in the liver, kidneys, lungs, and brain (fig 7). No tendency of a decreased relative occurrence of styrene glycol at higher doses was found either by the counting of the radioactivity in the ethyl acetate extracts or by the more specific method of gas chromatography with an electron capture detector (fig $7 \& 8$ ). Table 2 shows however that a smaller portion of the styrene glycol was bound to $\beta$-glucuronic acid or sulfate in the liver, kidneys, and lungs at higher doses. Furthermore the acidic metabolites and/or conjugates which remained in the aqueous phase after hydrolysis occurred at relatively lower levels at higher doses in all tissues except brain, the tissue with the lowest concentration of polar metabolites (fig 7).

\section{Discussion}

A rapid tissue distribution of styrene and its metabolites was observed after intraperitoneal administration to mice. An extensive tissue distribution of styrene has previously been indicated both in rats and mice by the fact that an apparent volume of distribution was much larger than the blood volume $(25,46,47)$.

The tissue concentration of styrene equivalents $2 \mathrm{~h}$ after the intraperitoneal administration of styrene differed; it was highest

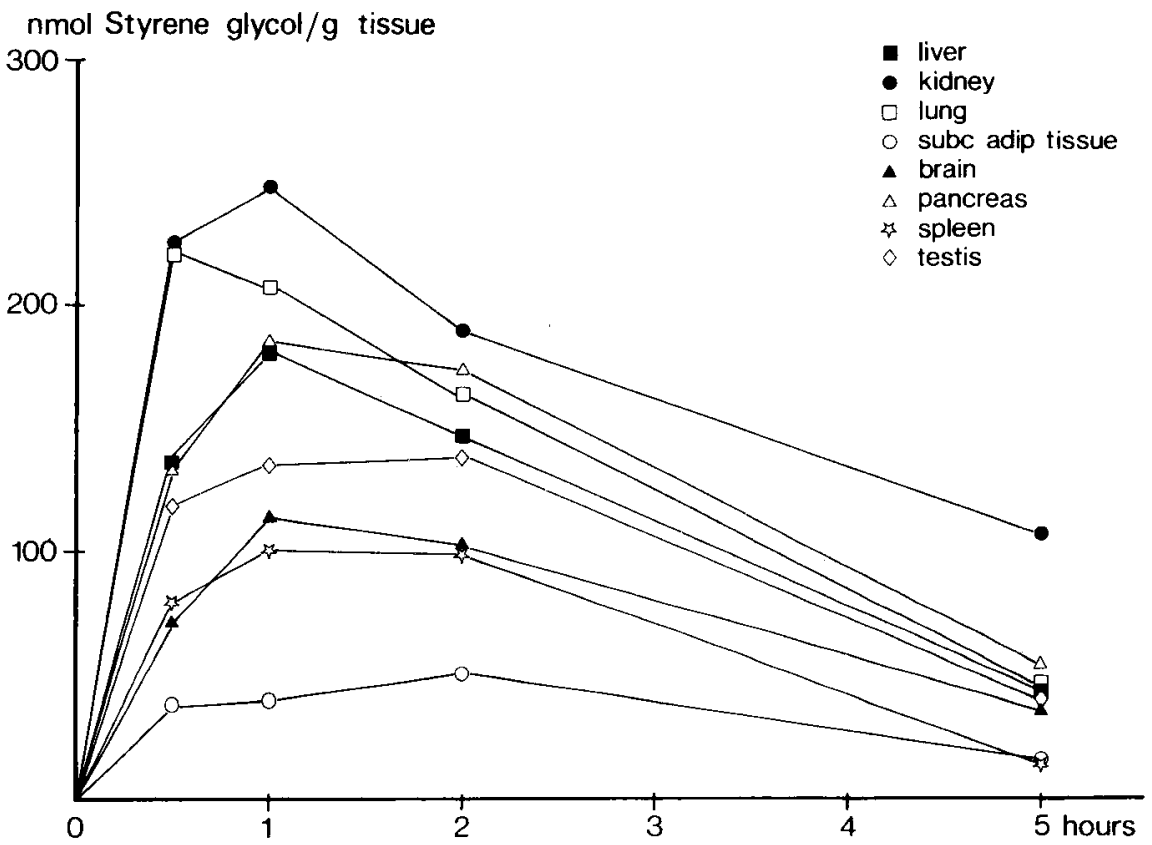

Fig 5. The sum of free and enzymatically liberated styrene glycol in different tissues as a function of time after the intraperitoneal administration of $7-\left[{ }^{14} \mathrm{C}\right]$-styrene in a concentration of $3.3 \mathrm{mmol} / \mathrm{kg}$. The concentration of styrene glycol is expressed as nanomoles of styrene glycol per gram of wet tissue. The styrene glycol was analyzed by gas chromatography. (subc adip = subcutaneous adipose) 


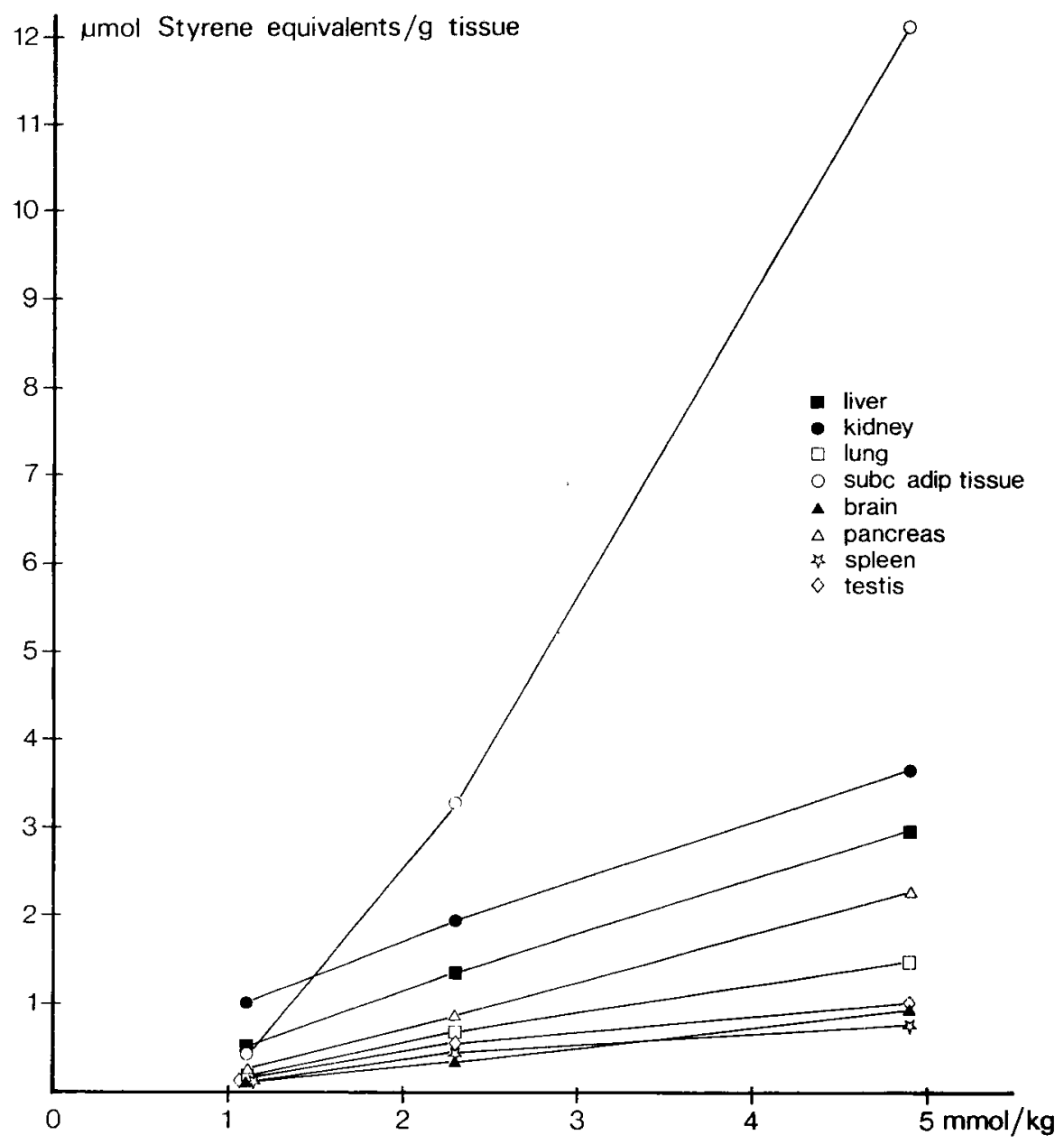

Fig 6. Tissue concentrations of styrene and its metabolites as a function of dose $2 \mathrm{~h}$ after the intraperitoneal administration of $7-\left[{ }^{14} \mathrm{C}\right]$-styrene in concentrations of $1.1,2.3$, and $4.9 \mathrm{mmol} / \mathrm{kg}$. The concentration of radioactivity is expressed as micromoles of styrene equivalents per gram of wet tissue based on the specific activity of the ${ }^{14} \mathrm{C}$-labeled styrene used. (subc adip = subcutaneous adipose)

in subcutaneous adipose tissue, and lower in the following tissues (presented in order of higher to lower concentration): kidneys, liver, lungs, and brain (fig 2). It was comparable with the distribution after inhalation exposure (5). Savolainen \& Vainio (34) reported the same distribution $3 \mathrm{~h}$ after the intraperitoneal injection of $0.6 \mathrm{mmol}(1.9$ $\mathrm{mmol} / \mathrm{kg}$ ) to rats, except for brain, which had the same amount of styrene equivalents as the kidneys.

The distribution of unmetabolized styrene differed in the tissues $1 \mathrm{~h}$ after the administration; it was highest in the adipose tissue and lower in the following tissues (presented in order of higher to lower concentration): liver, kidneys, brain, and lungs (fig 4). The same distribution pattern has been reported after the intraperitoneal injection of $200 \mathrm{mg} / \mathrm{kg}(1.9 \mathrm{mmol} / \mathrm{kg})$ to mice (25), and after the intravenous injection of $12-125 \mu \mathrm{mol} / \mathrm{kg}$ to rats (47). Immediately after a 4- to 5-h inhalation exposure to 500 to $1,000 \mathrm{ppm}$ of styrene more styrene was recovered in rat brain than in rat kidney, a finding in agreement with our results at the 30 -min sampling time $(37,46)$.

Pancreas had a high level of radioactivity, which consisted of almost $85 \%$ of the unmetabolized styrene, $30 \mathrm{~min}$ after the injection. This phenomenon may be related to the route of administration, but high amounts of labeled compounds have similarly been found in the pancreas after the 
LIVER
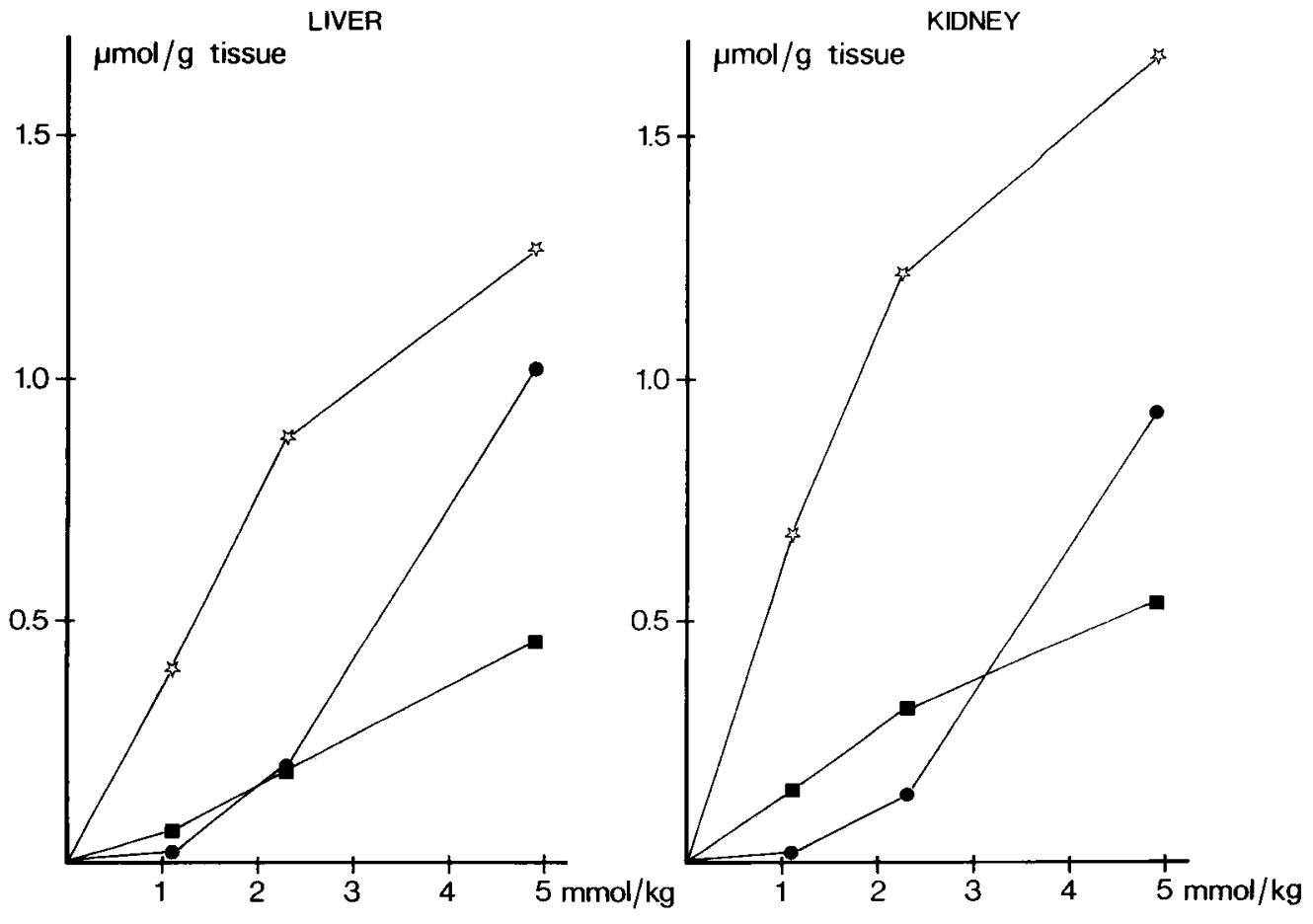

LUNG

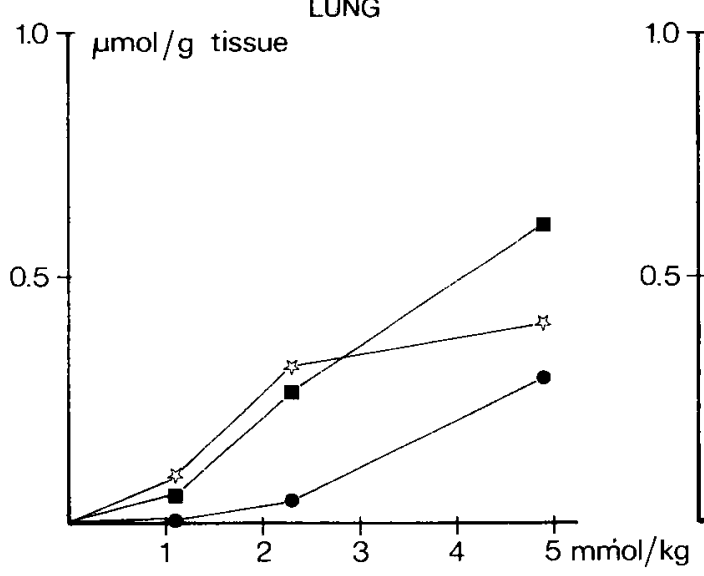

BRAIN

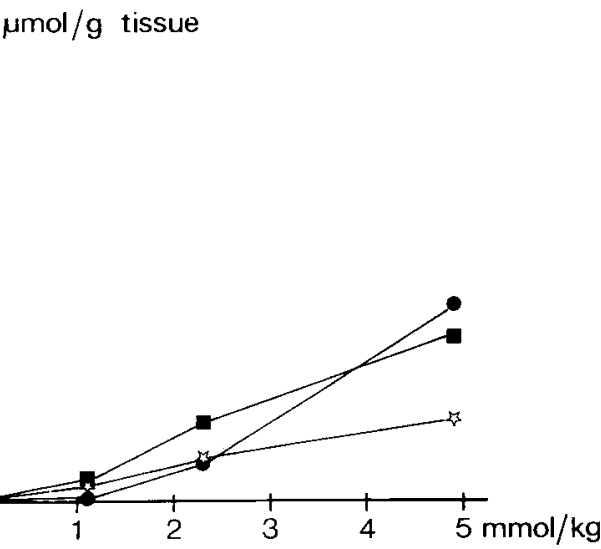

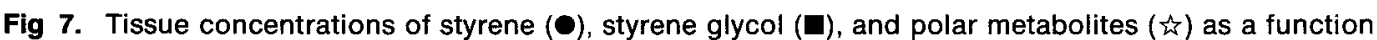
of dose $2 \mathrm{~h}$ after the intraperitoneal administration of $7-\left[{ }^{14} \mathrm{C}\right]$-styrene in concentrations of $1.1,2.3$, and $4.9 \mathrm{mmol} / \mathrm{kg}$. The concentration is expressed as micromoles per gram of wet tissue. The styrene glycol was analyzed by high-performance liquid chromatography.

oral administration of ${ }^{14} \mathrm{C}$-styrene to rats (29).

The concentration of styrene equivalents in subcutaneous adipose tissue decreased rapidly, a finding similar to the observation previously made for rats (8), and was already, after $5 \mathrm{~h}$, below the hepatic level. The concentration of unmetabolized styrene in subcutaneous adipose tissue was how- ever higher than in the liver at all times, a finding consistent with the high lipid solubility of styrene [see the report of Wigaeus et al (44)]. The half-time for styrene in adipose tissue has been reported to be $6 \mathrm{~h}$ in the rat (37) and about $72 \mathrm{~h}$ in man (15). The apparent half-times for styrene in all organs, as well as blood, have been reported to be much shorter in different species, 


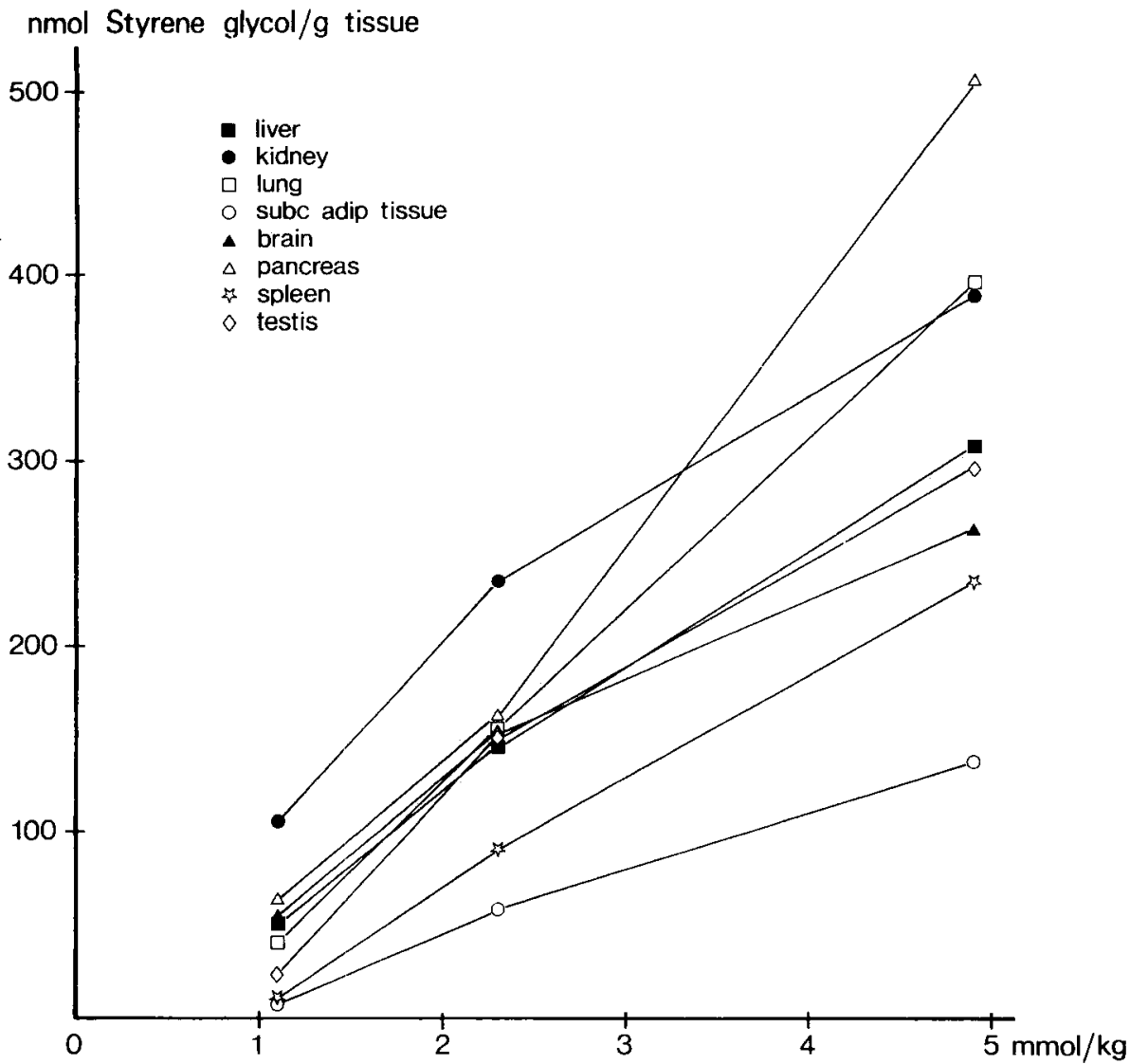

Fig 8. The sum of free and enzymatically liberated styrene glycol in different tissues as a function of dose $2 \mathrm{~h}$ after the intraperitoneal administration of $7-\left[{ }^{14} \mathrm{C}\right]$-styrene in concentrations of $1.1,2.3$, and $4.9 \mathrm{mmol} / \mathrm{kg}$. The concentration of styrene glycol is expressed as nanomoles of styrene glycol per gram of wet tissue. The styrene glycol was analyzed by gas chromatography. (subc adip = subcutaneous adipose)

Table 2. Tissue concentrations of styrene glycol, both free and conjugated with $\beta$-glucuronic acid or sulfate, $2 \mathrm{~h}$ after the intraperitoneal administration of $7-\left[{ }^{14} \mathrm{C}\right]$-styrene in a concentration of $1.1,2.3$, or $4.9 \mathrm{mmol} / \mathrm{kg}$. The concentration of styrene glycol was determined by gas chromatography.

\begin{tabular}{|c|c|c|c|c|c|c|}
\hline \multirow{3}{*}{ Tissue } & \multicolumn{6}{|c|}{ Administered amount of $7-\left[{ }^{14} \mathrm{C}\right]$-styrene } \\
\hline & \multicolumn{2}{|c|}{ 1. $1 \mathrm{mmol} / \mathrm{kg}$} & \multicolumn{2}{|c|}{$2.3 \mathrm{mmol} / \mathrm{kg}$} & \multicolumn{2}{|c|}{$4.9 \mathrm{mmol} / \mathrm{kg}$} \\
\hline & Freea & Conjugated ${ }^{a}$ & Free ${ }^{a}$ & Conjugated ${ }^{a}$ & Free $^{a}$ & Conjugateda \\
\hline $\begin{array}{l}\text { Liver } \\
\text { Kidney } \\
\text { Lung } \\
\text { Brain } \\
\text { Pancreas }\end{array}$ & $\begin{array}{l}40.9 \\
55.6 \\
33.5 \\
50.1 \\
58.1\end{array}$ & $\begin{array}{r}8.9 \\
49.6 \\
6.3 \\
1.6 \\
3.5\end{array}$ & $\begin{array}{l}124.0 \\
158.2 \\
143.3 \\
148.2 \\
154.4\end{array}$ & $\begin{array}{r}21.7 \\
76.9 \\
10.3 \\
4.1 \\
8.7\end{array}$ & $\begin{array}{l}278.1 \\
291.7 \\
374.5 \\
250.2 \\
488.2\end{array}$ & $\begin{array}{l}29.8 \\
87.0 \\
21.3 \\
12.8 \\
15.5\end{array}$ \\
\hline $\begin{array}{l}\text { Subcutaneous } \\
\text { adipose tissue } \\
\text { Spleen } \\
\text { Testis }\end{array}$ & $\begin{array}{r}6.7 \\
10.6 \\
23.3\end{array}$ & $\begin{array}{l}- \\
-\end{array}$ & $\begin{array}{r}57.1 \\
90.1 \\
142.1\end{array}$ & $\overline{-}$ & $\begin{array}{l}136.8 \\
234.3 \\
285.6\end{array}$ & $\begin{array}{c}- \\
\overline{10.4}\end{array}$ \\
\hline
\end{tabular}

a Styrene glycol (nmol/g wet tissue). 
about $40 \mathrm{~min}$ in the mouse $(25,37,44,46$, 47 ). In the present study the appearance of metabolites was very fast in all excretory organs. After $30 \mathrm{~min}$ the polar metabolites already constituted amounts equal to unmetabolized styrene in the liver and $60 \%$ of the total radioactivity in the kidneys. The high levels of radioactivity found in the kidneys probably reflect urinary excretion of polar metabolites (9).

Liver has the highest total activity of monooxygenase and epoxide hydratase of all tissues in the mouse (7). The contents of reduced glutathione and glutathione Stransferase are also highest in the liver (27). The lungs constitute the only organ with a higher activity of the monooxygenase system than of epoxide hydratase in vitro, a phenomenon which may render them very sensitive to the toxic effects of styrene exposure (7). At least $20-35 \%$ of the radioactivity in the lungs was styrene glycol in our study, mainly nonconjugated, a finding in agreement with a suspected low pulmonary activity of uridine 5'diphosphate-glucuronyltransferase [see the study of Gram (16)]. The occurrence of styrene metabolites has earlier been indicated in the lungs and liver of mice immediately after a 10-min inhalation exposure (5). Furthermore Ryan et al (32) reported that both conjugation with glutathione and hydration to styrene glycol were major pulmonary metabolic pathways of styrene-7,8-oxide in the rabbit, in spite of low activities of both glutathione S-transferases and epoxide hydratase in the lungs. The presence of a prominent portion of polar metabolites in the lungs in the present study may indicate a metabolism at the site and/or a difficulty for these metabolites to cross the cell membranes into the circulation.

Brain had a fairly high proportion of styrene glycol (25-50\%), despite low contents of monooxygenase and epoxide hydratase (27). Neither a metabolic turnover of styrene to styrene-7,8-oxide and further to styrene glycol in the brain nor a passage of styrene glycol from blood across the central nervous system barrier should be completely ruled out in spite of the low enzyme activities in the brain and the relatively poor lipid solubility of styrene glycol. A nonenzymatic transformation of styrene-7,8-oxide extracted from the blood or formed in the brain is also possible. The occurrence of styrene glycol in the brain is interesting, as this substance has been proclaimed to be a central nervous system depressant (28). No styrene metabolites have been detected in mouse brain earlier, but their presence has been implied in rat brain (8). Furthermore there have been indications of binding of styrene and/or styrene oxide both to proteins and glutathione in rat brain $(12,34)$.

Dose-dependent kinetics has been observed earlier for biphasic styrene elimination in the rat $(46,47)$. Both the rate of distribution and the rate of elimination decreased with increasing dose, while the apparent volume of distribution was unchanged (47). It has further been demonstrated that the clearance of styrene in the rat becomes saturated after exposure to between 200 and $600 \mathrm{ppm}$ for $6 \mathrm{~h}$ and results in an abrupt change in its steadystate level in blood at higher doses (30). This phenomenon can mainly be ascribed to a limited metabolic capacity, especially of the cytochrome P-450 system, which appears to be saturable also in the mouse. In the present investigation a dose-dependent occurrence of nonmetabolized styrene was noticed in all the tissues studied (fig 7). The conversion of styrene seemed to be reduced at the higher doses used.

No dose-dependent decrease in the degree of conversion of styrene to styrene glycol was observed (fig 7 \& 8). Styrene7,8 -oxide is a good substrate for the enzyme epoxide hydratase, which converts it into styrene glycol, the affinity being much higher than that of the monooxygenase system in rat liver microsomes $(3,13)$. At higher doses the conjugation of styrene glycol with $\beta$-glucuronic acid (or sulfate) seemed to approach saturation, and the socalled polar metabolites were not formed at the same rate. The polar metabolites can be subdivided into acids (oxidation products of styrene glycol) and glutathione conjugates (conjugation products of styrene-7,8-oxide). No attempt was made to separate them.

In the liver the concentration of the more polar metabolites exceeded that of styrene glycol by a factor of three at the highest dose (fig 7). This result agrees with the reported ratio of two between glutathione conjugates and styrene glycol formed from styrene-7,8-oxide by isolated 
rat liver (41). In the lungs the concentration of styrene glycol rose above that of the more polar metabolites after the highest dose given, while the concentrations were equal at lower doses (fig 7). A dose dependence in both glutathione conjugation and biliary excretion of styrene metabolites has earlier been indicated in the rat, along with dose-dependent urinary excretion of acidic styrene metabolites $(4,10$, $11,12,17,18,41)$. If the decreased relative formation of polar styrene metabolites noticed in several mouse tissues in the present study depends on a saturation of the capacity of the glutathione S-transferases, the detoxification of styrene-7,8oxide may be hampered. A study on the tissue concentrations of styrene-7,8oxide in the mouse after different doses of styrene is in progress in our laboratory.

\section{Acknowledgments}

The authors are very grateful to Professor M Mercier for his kind gift of allylbenzene glycol. We also wish to thank Ms E Lundgren for her skillful technical assistance.

\section{References}

1. Bakke OM, Scheline RR. Hydroxylation of aromatic hydrocarbons in the rat. Toxicol appl pharmacol 16 (1970) 691-700.

2. Bardodej Z, Bardodejova E. The metabolism of ethylbenzene, styrene and alphamethylstyrene. In: Proceedings of the 15 th international congress on occupational health. Volume II-1. Verlag der Wiener Medizinischen Akademie, Vienna 1966, pp 457-460.

3. Belvedere G, Pachecka J, Cantoni L, Mustini E, Salmona M. A specific gas chromatographic method for the determination of microsomal styrene monooxygenase and styrene epoxide hydratase activities. J chromatogr 118 (1976) 387393.

4. Bend JR, Smith BR, van Anda J, Ryan AJ, Fouts JR. Biotransformation of styrene oxide by the isolated perfused rat liver and by subfractions of homogenized liver cells. In: Fouts JR, Gut I, ed. Industrial and environmental xenobiotics. Excerpta Medica, Amsterdam 1978, pp 62-70.

5. Bergman $K$. Whole-body autoradiography and allied tracer techniques in distribution and elimination studies of some organic solvents: Benzene, toluene, xylene, styrene, methylene chloride, chloroform, carbon tetrachloride and trichloroethylene. Scand j work environ health 5 (1979): suppl 1, 93-120.
6. Boyland E, Williams K. An enzyme catalysing the conjugation of epoxides with glutathione. Biochem j 94 (1965) 190-197.

7. Cantoni L, Salmona M, Facchinetti T, Pantarotto C, Belvedere G. Hepatic and extrahepatic formation and hydration of styrene oxide in vitro in animals of different species and sex. Toxicol lett 2 (1978) 179186.

8. Carlsson A. Distribution and elimination of ${ }^{14} \mathrm{C}$-styrene in rat. Scand $\mathbf{j}$ work environ health 7 (1981) 45-50.

9. Danishefsky I, Willhite M. The metabolism of styrene in the rat. $\mathrm{J}$ biol chem 211 (1954) $549-553$.

10. Das M, Dixit R, Mushtaq M, Srivastava SP, Seth PK. Effect of styrene on hepatic mixed function oxidases, glutathione content and glutathione-S-transferase activity in rats. Drug chem toxicol 4 (1981) 219-227.

11. Das M, Srivastava SP, Seth PK. Effect of styrene on glutathione content and some xenobiotic metabolizing enzymes of rat kidney. Acta pharmacol toxicol 52 (1983) 4750 .

12. Dixit R, Das M, Mushtaq M, Srivastava SP, Seth PK. Depletion of glutathione content and inhibition of glutathione-S-transferase and aryl hydrocarbon hydroxylase activity of rat brain following exposure to styrene. Neuro toxicol 3 (1982) 142-145.

13. Duverger-van Bogaert $M$, Noel $G$, Rollman B, Cumps J, Roberfroid M, Mercier M. Determination of oxide synthetase and hydratase activities by a new highly sensitive gas chromatographic method using styrene and styrene oxide as substrates. Biochim biophys acta 526 (1978) 77-84.

14. El Masri AM, Smith JN, Williams RT. Studies in detoxication: 73. The metabolism of alkylbenzenes: Phenylacetylene and phenylethylene (styrene). Biochem j 68 (1958) $199-204$.

15. Engström J, Bjurström R, Åstrand I, Övrum $P$. Uptake, distribution and elimination of styrene in man: Concentration in subcutaneous adipose tissue. Scand $\mathrm{j}$ work environ health 4 (1978) 315-323.

16. Gram TE. The metabolism of xenobiotics by mammalian lung. In: Vesell ES, Garattini S, ed. Monographs in pharmacology and physiology. Volume 5 (Extrahepatic metabolism of drugs and other foreign compounds). Spectrum publications, New York, NY 1980, pp 159-209.

17. Ikeda M, Hirayama T. Possible metabolic interaction of styrene with organic solvents. Scand j work environ health 4 (1978): suppl 2, 41-46.

18. Ikeda M, Imamura $T$, Hayashi $M$, Tabuchi T, Hara I. Evaluation of hippuric, phenylglyoxylic and mandelic acids in urine as indices of styrene exposure. Int Arch Arbeitsmed 32 (1974) 93-101.

19. James SP, White DA. The metabolism of phenethyl bromide, styrene and styrene oxide in the rabbit and rat. Biochem j 104 (1967) 914-921.

20. Leibman KC. Metabolism and toxicity of styrene. Environ health perspect 11 (1975) 115-119. 
21. Leibman KC, Ortiz E. Styrene epoxide An intermediate in microsomal oxidation of styrene to its glycol. Pharmacologist 10 (1968) 203

22. Leibman KC, Ortiz E. Epoxide intermediates in microsomal oxidation of olefins to glycols. J pharmacol exp ther 173 (1970) $242-246$.

23. Oesch F, Jerina DM, Daly J. A radiometric assay for hepatic epoxide hydrase activity with $(7-3 \mathrm{H})$ styrene oxide. Biochim biophys acta 227 (1971) 685-691.

24. Ohtsuji $H$, Ikeda M. The metabolism of styrene in the rat and the stimulatory effect of phenobarbital. Toxicol appl pharmacol 18 (1971) 321-328.

25. Pantarotto C, Fanelli R, Belletti I, Bidoli F. Determination of styrene in biological specimens by gas chromatography - Selected ion monitoring: Distribution in mice. Anal biochem 105 (1980) 340-347.

26. Pantarotto C, Fanelli R, Bidoli F, Morazzoni $\mathrm{P}$, Salmona M, Szczawinska $\mathrm{K}$. Arene oxides in styrene metabolism, a new perspective in styrene toxicity? Scand $\mathrm{j}$ work environ health 4 (1978): suppl 2, 67-77.

27. Pantarotto C, Salmona M, Szczawinska K, Bidoli F. Gas chromatographic-mass spectrometric studies on styrene toxicity. In: A'lbaiges J, ed. Analytical techniques in environmental chemistry. Pergamon Press, Oxford 1980, pp 245-279.

28. Parkki MG, Marniemi J, Vainio H. Action of styrene and its metabolites styrene oxide and styrene glycol on activities of xenobiotic biotransformation enzymes in rat liver in vivo. Toxicol appl pharmacol 38 (1976) 59-70.

29. Plotnick HB, Wiegel WW. Tissue distribution and excretion of ${ }^{14} \mathrm{C}$-styrene in male and female rats. Res commun chem pathol pharmacol 24 (1979) 515-524.

30. Ramsey JC, Young JD. Pharmacokinetics of inhaled styrene in rats and humans. Scand j work environ health 4 (1978): suppl 2, 84-91.

31. Ryan AJ, Bend JR. The metabolism of styrene oxide in the isolated perfused rat liver: Identification and quantitation of major metabolites. Drug metab dispos 5 (1977) 363-367.

32. Ryan AJ, James MO, Ben-Zvi Z, Law FCP, Bend JR. Hepatic and extrahepatic metabolism of ${ }^{14} \mathrm{C}$-styrene oxide. Environ health perspect 17 (1976) 135-144.

33. Sandell J, Parkki MG, Marniemi J, Aitio A. Effects of inhalation and cutaneous exposure to styrene on drug metabolizing enxymes in the rat. Res commun chem pathol pharmacol 19 (1978) 109-118.

34. Savolainen $\mathrm{H}$, Vainio $\mathrm{H}$. Organ distribution and nervous system binding of styrene and styrene oxide. Toxicology 8 (1977) 135-141.

35. Seutter-Berlage F, Delbressine LPC, Smeets FLM, Ketelaars HCJ. Identification of three sulphur-containing urinary metabolites of styrene in the rat. Xenobiotica 8 (1978) 413-418.

36. Steele JW, Yagen B, Hernandez O, Cox RH, Smith BR, Bend JR. The metabolism and excretion of styrene oxide-glutathione conjugates in the rat and by isolated perfused liver, lung and kidney preparations. J pharmacol exp ther 219 (1981) 35-41.

37. Teramoto $\mathrm{K}$, Horiguchi S. Absorption, distribution and elimination of styrene in man and experimental animals. Arc hig rada toksikol 30 (1979): suppl, 431-437.

38. Tossavainen A. Styrene use and occupational exposure in the plastics industry. Scand j work environ health 4 (1978): suppl 2, 7-13.

39. Vainio H, Mäkinen A. Styrene and acrylonitrile induced depression of hepatic nonprotein sulfhydryl content in various rodent species. Res commun chem pathol pharmacol 17 (1977) 115-124.

40. Vainio H, Tursi F, Belvedere G. What are the significant toxic metabolites of styrene? In: Hietanen $\mathrm{E}$, Laitinen M, Hänninen O, ed. Cytochrome P-450, biochemistry, biophysics and environmental implications. Elsevier Biomedical Press BV, Amsterdam 1982 , pp 679-687.

41. Van Anda J, Smith BR, Fouts JR, Bend JR. Concentration-dependent metabolism and toxicity of ${ }^{14} \mathrm{C}$-styrene oxide in the isolated perfused rat liver. J pharmacol exp ther 211 (1979) 207-212.

42. Watabe T, Isobe M, Sawahata T, Yoshikawa K, Yamada S, Takabatake E. Metabolism and mutagenicity of styrene. Scand $\mathrm{j}$ work environ health 4 (1978): suppl 2, 142-155.

43. Watabe $T$, Isobe $M$, Yoshikawa $K$, Takabatake E. Studies on metabolism and toxicity of styrene: I Biotransformation of styrene to styrene glycol via styrene oxide by rat liver microsomes. J Pharmacobio dyn 1 (1978) 98-104.

44. Wigaeus E, Löf A, Bjurström R, Byfält Nordqvist M. Exposure to styrene: Uptake, distribution, metabolism and elimination in man. Scand j work environ health (in press).

45. Wilson HK, Robertson SM, Waldron HA, Gompertz D. Effect of alcohol on the kinetics of mandelic acid excretion in volunteers exposed to styrene vapour. $\mathrm{Br} \mathrm{j}$ ind med 40 (1983) $75-80$.

46. Withey JR. The toxicology of styrene monomer and its pharmacokinetics and distribution in the rat. Scand $\mathrm{j}$ work environ health 4 (1978): suppl $2,31-40$.

47. Withey JR, Collins PG. Pharmacokinetics and distribution of styrene monomer in rats after intravenous administration. $\mathrm{J}$ toxicol environ health 3 (1977) 1011-1020.

Received for publication: 4 July 1983 